\title{
Efficacy and safety of everolimus treatment in a hemodialysis patient with metastatic atypical bronchial carcinoid: case report and literature review
}

\author{
M. P. Brizzi ${ }^{1}{ }^{*}$, A. La Salvia ${ }^{1}$, M. Tampellini ${ }^{1}$, C. Sonetto ${ }^{1}$, M. Volante $^{2}$ and G. V. Scagliotti ${ }^{1}$
}

\begin{abstract}
Background: Everolimus was recently approved for the treatment of neuroendocrine tumors. However, its efficacy and tolerability in hemodialysis patients with end-stage renal disease is not established.

Case presentation: We describe the case of a 47-year-old man with end-stage renal disease who received everolimus plus Lanreotide for 9 months for the management of metastatic atypical bronchial carcinoid.

Conclusions: Everolimus is a treatment option for hemodialysis patients with metastatic atypical bronchial carcinoid. Based on our case report and review of literature, Everolimus does not require any dose reductions and is overall well tolerated in hemodialysis patients.
\end{abstract}

Keywords: Bronchial carcinoids, Everolimus, Hemodialysis, Pharmacokinetics, Safety

\section{Background}

In two phase III trials everolimus has been shown to be active against neuroendocrine tumors (NETs) arising from the lung $[1,2]$. Its tolerability in lung NET patients with concomitant severe renal insufficiency has never been reported. Here we describe the case of a hemodialysis patient with metastatic atypical bronchial carcinoid treated with everolimus.

\section{Case presentation}

In February 2011, a 47-year-old white male patient underwent right lung lobectomy for resection of an atypical bronchial carcinoid (pT1pN2). His medical history was significant for end-stage renal disease (ESRD) secondary to focal segmental glomerulosclerosis requiring iterative hemodialysis. In September 2011 a right hepatectomy was performed due to liver metastases; metastatic

* Correspondence: mariapia.brizzi@email.it

${ }^{1}$ Medical Oncology, Department of Oncology, University of Turin, Azienda

Ospedaliera Universitaria San Luigi, Regione Gonzole 10, 10043, Orbassano,

Turin, Italy

Full list of author information is available at the end of the article disease progressed to liver and bone over the next 17 months. Monthly administration of intramuscular Lanreotide $120 \mathrm{mg}$ was initiated and continued for 1 year. In March 2014 further disease progression was noted and oral everolimus was initiated at a dose of $10 \mathrm{mg} /$ day, then reduced to $5 \mathrm{mg} /$ day 1 month later due to persistent grade II mucositis. No grade III-IV toxicities occurred. A computed tomography (CT) scan taken 3 months later showed stabilization of disease. Everolimus therapy was discontinued in November 2014, after a 9-month course of treatment, because of hepatic and bone disease progression. Somatostatin analogue therapy was continued throughout. A CT scan taken 6 months later revealed progression of liver disease and development of peritoneal metastases, for which 5 cycles of chemotherapy with temozolomide were administered from April to August 2015. Liver metastases and peritoneal metastases progressed, and oral metronomic chemotherapy with capecitabine was initiated in November 2015. The patient died in January 2016 due to disease progression. 
Table 1 Everolimus in the treatment of hemodialysis patients with metastatic renal cell carcinomas

\begin{tabular}{|c|c|c|c|c|c|c|c|}
\hline Authors/reference & Study description & $\begin{array}{l}\text { No. of patients } \\
\text { included }\end{array}$ & $\begin{array}{l}\text { No. of prior } \\
\text { regimen }\end{array}$ & $\begin{array}{l}\text { Everolimus } \\
\text { dosage }\end{array}$ & $\begin{array}{l}\text { Best } \\
\text { responses }\end{array}$ & $\begin{array}{l}\text { Duration of } \\
\text { response }\end{array}$ & Safety \\
\hline $\begin{array}{l}\text { Thiery-Vuillemin A } \\
\text { et al. [9] }\end{array}$ & Case reports & 2 & $1 ; 1$ & $5 \mathrm{mg}$ & NA & NA & $\begin{array}{l}\text { Grade II asthenia, } \\
\text { diarrhea and mucositis; } \\
\text { grade III hyperglycemia }\end{array}$ \\
\hline Syrios J et al. [10] & Case reports & 2 & $1 ; 1$ & $10 \mathrm{mg}$ & $\mathrm{SD} ; \mathrm{CR}$ & $4 \mathrm{mo} ; 40 \mathrm{mo}$ & Well tolerated \\
\hline Adytia $\vee$ et al. [11] & $\begin{array}{l}\text { Single institution } \\
\text { experience }\end{array}$ & 6 & NA & $\begin{array}{l}10 \mathrm{mg} ; 1 \text { dosage } \\
\text { reduction to } 5 \mathrm{mg}\end{array}$ & SD & $\begin{array}{l}\text { Median duration } \\
\text { of therapy } 1.9 \mathrm{mo} \\
(0.4-17)\end{array}$ & $\begin{array}{l}5 \text { patients: well tolerated, } \\
1 \text { patient: pneumonitis }\end{array}$ \\
\hline $\begin{array}{l}\text { Czarnecka AM et al. } \\
\text { [12] }\end{array}$ & $\begin{array}{l}\text { Single institution } \\
\text { experience }\end{array}$ & 1 & 2 & $10 \mathrm{mg}$ & PD & $4 \mathrm{mo}$ & Well tolerated \\
\hline Omae K et al. [13] & $\begin{array}{l}\text { Single institution } \\
\text { experience }\end{array}$ & 4 & 1 & & SD & $\begin{array}{l}\text { Median duration } \\
\text { of therapy } 6.7 \text { mo }\end{array}$ & $\begin{array}{l}\text { Grade II rash, diarrhea, } \\
\text { pneumonitis, and mucositis }\end{array}$ \\
\hline
\end{tabular}

Abbreviations: NA Not available, SD Stable disease, PD Progression of disease, mo Months

\section{Discussion and conclusions}

Several therapeutic options are available for front-line treatment of metastatic bronchial carcinoids, including somatostatin analogues, chemotherapy, and peptide receptor radionuclide therapy [3].

However, comorbidities such as renal failure can limit or even preclude such treatments [4].

Unfortunately, there are no established guidelines for the administration of chemotherapeutic or target agents in hemodialysis patients [5]. The prevalence of renal insufficiency in cancer patients is growing [6], making observations in any tumor setting important.

To the best of our knowledge, this is the first report of a hemodialysis patient with metastatic atypical bronchial carcinoid treated with everolimus. In the one case of a hemodialysis patient with metastatic ileal well differentiated NET (G1) described so far, disease stabilization was achieved without any adverse effects [7].

Clinical trials investigating everolimus activity have excluded ESRD patients because the condition is thought to alter drug pharmacokinetics. Indeed, drug clearance may be different in hemodialysis patients, increasing the risk of overdosage and higher toxicities [8], or it may be more rapid and thus reduce drug efficacy. Recent reports have documented that everolimus pharmacokinetics is not altered by hemodialysis in patients with metastatic renal cell cancer [9-13], probably owing to the absence of diffusion of everolimus through commonly used dialysis membranes and in the dialysate fluid (Table 1). Another explanation for the unchanged tolerability profile of everolimus in patients with renal insufficiency is that the drug is predominantly metabolized by the liver and eliminated in the bile [14].

Moreover, repeated surgery for multiple renal cell carcinoma in patients with von Hippel-Lindau syndrome may lead to ESRD in up to $25 \%$ of cases [15]. In these young patients, pancreatic NETs occurrence is frequent. Treatment with everolimus may be considered safe in this patient setting. Everolimus therapy is feasible in hemodialysis patients with metastatic bronchial carcinoid. Its observed efficacy and tolerability profile are similar to those reported in patients with normal renal function. To confirm the clinical features of everolimus in NET patients undergoing hemodialysis, data collection from single case or case series is highly envisioned. This will remove any concern about treating this rare patient subgroup with an active treatment allowing their inclusion in prospective trials.

\section{Abbreviations \\ CT: Computed tomography; ESRD: End-stage renal disease; G1: Grade 1; Mg: Milligrams; NET: Neuroendocrine tumor; NETs: Neuroendocrine tumors; pT1pN2: UICC pathological TNM staging system}

\section{Acknowledgements}

None

\section{Funding}

This research did not receive any specific grant from funding agencies in the public, commercial, or not for-profit sectors.

\section{Availability of data and materials}

The data used and/or analyzed during the current study are available from the corresponding author on reasonable request.

\section{Authors' contributions}

MPB, ALS and CS followed the patient; they acquired data, conceived and carried out the study, drafted the manuscript; MV performed the histological diagnoses and drafted the manuscript; MT and GVS revised manuscript critically and supported financially the pubblication. All authors have given their approval of the final version of the manuscript.

\section{Ethics approval and consent to participate}

Patient written informed consent has been obtained to partecipate. A copy of the consent form is available for review by the Editor of this journal.

Consent for pubblication

Patient written informed consent has been obtained for pubblication.

\section{Competing interests}

The authors declare that they have no competing interests.

\section{Publisher's Note}

Springer Nature remains neutral with regard to jurisdictional claims in published maps and institutional affiliations. 


\section{Author details}

'Medical Oncology, Department of Oncology, University of Turin, Azienda Ospedaliera Universitaria San Luigi, Regione Gonzole 10, 10043, Orbassano, Turin, Italy. ${ }^{2}$ Department of Medical Oncology and Pathology, University of Turin, Azienda Ospedaliera Universitaria San Luigi, Regione Gonzole 10, 10043, Orbassano, Turin, Italy.

Received: 21 March 2017 Accepted: 9 March 2018

\section{Published online: 20 March 2018}

\section{References}

1. Yao JC, Fazio N, Singh S, Buzzoni R, Carnaghi C, Wolin E, et al. Everolimus for the treatment of advanced, non-functional neuroendocrine tumours of the lung or gastrointestinal tract (RADIANT-4): a randomised, placebocontrolled, phase 3 study. RAD001 in advanced neuroendocrine Tumours, fourth trial (RADIANT-4) study group. Lancet. 2016;387(10022):968-77.

2. Fazio N, Granberg D, Grossman A, Saletan S, Klimovsky J, Panneerselvam A et al. Everolimus plus octreotide long-acting repeatable in patients with advanced lung neuroendocrine tumors: analysis of the phase 3 , randomized, placebo-controlled RADIANT-2 study. Chest. 2013;143(4):955-62.

3. Caplin ME, Baudin E, Ferolla P, Filosso P, Garcia-Yuste M, Lim E, et al. ENETS consensus conference participants. Pulmonary neuroendocrine (carcinoid) tumors: European neuroendocrine tumor society expert consensus and recommendations for best practice for typical and atypical pulmonary carcinoids. Ann Oncol. 2015;26(8):1604-20.

4. Mao FJ, Rini BI. The ineligible patient: how to treat patients not included in clinical studies. World J Urol. 2014;32(1):9-18.

5. Launay-Vacher V, Oudard S, Janus N, Gligorov J, Pourrat X, Rixe O, et al. Prevalence of renal insufficiency in cancer patients and implications for anticancer drug management: the renal insufficiency and anticancer medications (IRMA) study. Cancer. 2007;10(6):1376-84.

6. Cengis $K$. Increased incidence of neoplasia in chronic renal failure. Int Urol Nephrol. 2002;33(1):121-6.

7. Van Rooijen JM, De Vries EG. Hemodialysis no reason to withhold everolimus. Cancer Chemother Pharmacol. 2013;71(1):273-4.

8. Janus $\mathrm{N}$, Thariat J, Boulanger H, Deray G, Launay-Vacher V. Proposal for dosage adjustment and timing of chemotherapy in hemodialyzed patients. Ann Oncol. 2010;21(7):1395-403.

9. Thiery-Vuillemin A, Curtit E, Maurina T, Montange D, Succi C, Nguyen T, et al. Hemodialysis does not affect everolimus pharmacokinetics: two cases of patients with metastatic renal cell cancer. Ann Oncol. 2012;23(11):2992-3.

10. Syrios J, Kechagias G, Tsavaris N. Treatment of patients with metastatic renal cell carcinoma undergoing hemodialysis: case report of two patients and short literature review. BMC Nephrol. 2013;14:84.

11. Aditya V, Matrana MR, Atkinson BJ, Flaherty AL, Jonasch E, Tannir NM. Outcomes of patients with metastatic renal cell carcinoma and end-stage renal disease receiving Dialysis and targeted therapies: a single institution experience. Clin Genitourin Cancer. 2014;12(5):348-53.

12. Czarnecka AM, Kawecki M, Lian F, Korniluk J, Szczylik C. Feasibility, efficacy and safety of tyrosine kinase inhibitor treatment in hemodialyzed patients with renal cell cancer: 10 years of experience. Future Oncol. 2015;11(16): 2267-82.

13. Omae $K$, Kondo T, Takagi T, lizuka J, Kobayashi H, Hashimoto $Y$, et al. Use of mammalian target of rapamycin inhibitors after failure of tyrosine kinase inhibitors in patients with metastatic renal cell carcinoma undergoing hemodialysis: a single-center experience with four cases. Hemodial Int. 2016; 20(3):E1-5.

14. Grgic T, Mis L, Hammond JM. Everolimus: a new mammalian target of rapamycin inhibitor for the treatment of advanced renal cell carcinoma. Ann Pharmacother. 2011;45(1):78-83.

15. Steinbach F, Novick AC, Zincke H, Miller DP, Williams RD, Lund G, et al. Treatment of renal cell carcinoma in Von Hippel-Lindau disease: a multicenter study. J Urol. 1995;153(6):1812-6.

\section{Submit your next manuscript to BioMed Central and we will help you at every step:}

- We accept pre-submission inquiries

- Our selector tool helps you to find the most relevant journal

- We provide round the clock customer support

- Convenient online submission

- Thorough peer review

- Inclusion in PubMed and all major indexing services

- Maximum visibility for your research

Submit your manuscript at www.biomedcentral.com/submit
Biomed Central 